\title{
HUMAN HEALTH RISK ASSESSMENT DUE TO CADMIUM ACCUMULATION THROUGH CONSUMPTION OF CHINESE CABBAGE GROWN IN CADMIUM-CONTAMINATED SOIL
}

\author{
Mahmud, M. A., M. Hassan, R. Hassan, R. Mandal and M. K. Rahman \\ Department of Soil, Water and Environment, University of Dhaka, Dhaka-1000, Bangladesh
}

\begin{abstract}
Heavy metal like Cadmium $(\mathrm{Cd})$ is a common pollutant present in the soils of urban and industrial areas. Vegetables are preferably grown in these soils than other crops. Of the vegetables, Chinese cabbage (Brassica campestris var. pekinensis) is gaining its popularity among farmers for its high market value. Therefore, an experiment was conducted where cabbage was grown on $\mathrm{Cd}$ treated soil. Bioaccumulation of $\mathrm{Cd}$ in Chinese cabbage was determined and Target Hazard Quotient (THQ) model was used to assess potential health risk of human. Results showed that with increasing concentration of added $\mathrm{Cd}(0.00$ to $4.00 \mathrm{ppm})$ in soil, bio-concentration factors of $\mathrm{Cd}$ of Chinese cabbage also increased except at $4 \mathrm{ppm}$. The chinese cabbage grown in Cd contaminated soils up-to $1.00 \mathrm{ppm}$ might be safe. However, cabbage grown in the soils contaminated with $\mathrm{Cd}$ above this level would probably be risky and may cause serious health hazard to human body.
\end{abstract}

Key words: Cadmium, Chinese cabbage, THQ model, Bio-concentration factors, Human health risk assessment.

\section{INTRODUCTION}

Bioaccumulation is the process in which persistent toxins are passed along the food chain and accumulate in progressively higher concentrations. When a relative accumulation of pollutants gets up the food chain in more complex organisms, at least for the toxins that are stored in some way, the way may be called bioaccumulation (Bashar 2004). It is a general rule that as pollution increases, the physiological and genetic health of animal populations decline and eventually the number of species in the polluted ecosystem declines. In this process the plants that are affected, for example, may be eaten by small animals with little adverse effect, but as the relative pollution levels rise toxins become concentrated higher up the food chain, where the effects can be magnified, it is not quite that simple, because higher up a food chain, larger creatures may have a greater resistant or ability to deal with poisoning (Woodwell 1967).

Cadmium (Cd), one of the most environmental hazardous heavy metals, has been released into the environment by different human activities; for example, leather processing, electroplating, metalcontaining sewage sludge and fertilizers (Zhou et al. 2002, Zhou 2003). Rapid uptake and bioaccumulation of $\mathrm{Cd}$ in food chain makes this element a potential environmental hazard (De 1989). Cadmium is extremely toxic to animals and causes severe problem in kidneys, liver, gastrointestinal tract, heart, testes, pancreas, bones and blood vessels (Conway and Pretty 1991). The food plants grown in Cd contaminated soils may have possibility of high Cd uptake (Mengal and Kirkby 1987).

Vegetables cultivated in the soils, polluted with toxic and heavy metals, take up such metals and accumulate them in their edible and non-edible parts in quantities high enough to cause clinical problems both to animals and human beings consuming these metal-rich plants as there is no good mechanism for their elimination from the human body (Alam et al. 2003, Bhuiyan et al. 2011). But by the help of enrichment factor, estimation of metal entry in plant body from metal contaminated soil can be made. Enrichment factor is defined as the ratio of particular element content in a plant to the soil. This was first proposed for the source diagnosis of atmospheric particulate matter in the Antartic (Zoller et al. 1974). Recently, enrichment factor is used in the soil, water and sediment research as transfer factor, bio concentration factor (BCF) and plant uptake factor. This ratio is also used for the assessment of heavy metal pollution in environmental geochemistry (Khan et al. 2010, Delgado et al. 2012, 
Brioschi et al. 2013). BCF is used as indicator for estimating the metal transfer from soil into plant (USEPA 2005). In leafy vegetables, tubers and fruit vegetables, BCF-based research shows that the extent of metal enrichment in vegetables is highest (Liu et al. 2012, Pandey and Pandey 2009). Regarding metal concentrations, cadmium (Cd) commonly occurs at high levels in leafy vegetables (Ngole 2011).

Chinese cabbage (Brassica campestlris var. pekinensis) belonging to the family Cruciferae is an important leafy, herbaceous vegetable widely grown crop and said to be originated in China (Rashid 1999). It is gaining popularity among farmers for its rapid growth, high yield and economic return. The productions of different cabbages are increasing each year (BBS 2015). In the Dhaka division, Savar agricultural area is extensively used for vegetable production. Due to different anthropogenic activities like textile industry, pharmaceuticals companies, low grade fertilizer application, automobile etc., the soils of Savar, Bangladesh are contaminated with $\mathrm{Cd}$ and become very risky to grow leafy vegetable (Aktaruzzaman et al. 2013). Thus, the objectives of this study were to evaluate the potential accumulation capacity of Chinese cabbage for $\mathrm{Cd}$. Moreover, bio concentration factor to assess the potential human health risks of $\mathrm{Cd}$ metal exposure to the Dhaka city residents through consumption of contaminated Chinese cabbage was evaluated using the Target Hazard Quotient (THQ) (USEPA 2002). The THQ, which is the ratio between the exposure and the reference dose (RfD), is used to express the risk of non-carcinogenic effects. Ratio of less than 1 signifies non-obvious risk. Conversely, an exposed population of concern will experience health risk if the dose is equal to or greater than the RfD. The method for the determination of THQ was provided in the United States EPA Region III risk-based concentration table (USEPA 1989).

\section{Field site and soil characterization}

\section{MATERIAL AND METHODS}

A pot experiment was carried out in the net house of the Department of Soil Water and Environment, University of Dhaka. Soil samples (0-20 cm depths) were collected from the field near Bangobondhu Shekh Mujibur Rahman Hall, Jahangirnagar University. Some physico-chemical properties of the soil determined are as follows: $\mathrm{pH} 6.48\left(1: 2.5 \mathrm{~W} / \mathrm{V} \mathrm{H}_{2} \mathrm{O}\right)$, sand $10 \%$, silt $62 \%$ and clay $28 \%$, textural class silty clay loam (Piper 1944), CEC $28.71 \mathrm{me} / 100 \mathrm{~g}$ soil, soil colour - red and organic carbon $1.24 \%$ (Jackson 1958). Total nitrogen 0.30\% (Marr and Cresser 1983), total phosphorus 0.04\% (Jackson 1967), potassium $0.24 \%$, sulphur $0.01 \%$ (Klute 1986) and cadmium (Wei et al. 2005) - below detection limit.

\section{Experimental procedure}

Three kilogram air-dry soil (passed through $3 \mathrm{~mm}$ sieve) was used per plastic pot. Treatments used were Control (without $\mathrm{Cd}$ ), $0.25 \mathrm{ppm} \mathrm{Cd} / 3 \mathrm{~kg}$ soil, $0.50 \mathrm{ppm} \mathrm{Cd} / 3 \mathrm{~kg}$ soil, $1.0 \mathrm{ppm} \mathrm{Cd} / 3 \mathrm{~kg}$ soil, 1.5 ppm $\mathrm{Cd} / 3 \mathrm{~kg}$ soil, $2.0 \mathrm{ppm} \mathrm{Cd} / 3 \mathrm{~kg}$ soil, $3.0 \mathrm{ppm} \mathrm{Cd} / 3 \mathrm{~kg}$ soil, and $4.0 \mathrm{ppm} \mathrm{Cd} / 3 \mathrm{~kg}$ soil. Cadmium Chloride $\left(\mathrm{CdCl}_{2} \cdot 2.5 \mathrm{H}_{2} \mathrm{O}\right)$ was applied in the pots as per treatment. Treatment $0.00 \mathrm{ppm}$ stands for unpolluted. Treatment $0.25,0.50$ and 1.00 stands for unpolluted to moderately pollute. Treatment 1.50 and $2.00 \mathrm{ppm}$ stand for moderately polluted and treatment $3.00 \mathrm{ppm}$ stands for moderately to strongly pollute. Lastly, $4.00 \mathrm{ppm}$ stands for strongly polluted (Muller 1969). Eight treatments replicated thrice were arranged in a completely randomized design (CRD). Chinese cabbage seeds were collected from Rajdhani Seed Company, Siddique Bazar, Dhaka. Before sowing, the seeds were sterilized in $2 \%$ (v/v) hydrogen peroxide for 10 minutes, washed several times with distilled water and soaked in water overnight. Five seeds were sown per plot and finally two seedlings were allowed to grow. Seedlings were irrigated with tap water. Intercultural operations, viz. weeding, pesticide application etc., were done 
as and when needed. Plants were harvested as root and leaf after twelve weeks of growth. Heights were recorded at the time of harvest.

\section{Plant sample preparation and analysis}

Leaf samples were collected and wiped with a piece of white cloth and washed with distilled water. Root samples were washed with tap water and finally with distilled water to remove soil particles. The samples were then dried at $70^{\circ} \mathrm{C}$ in an oven until completely dry. The dried plant samples were grinded and kept in polyethylene bag for chemical analysis. The leaf sample $(0.1 \mathrm{~g})$ was digested with $12 \mathrm{ml}$ solution of concentrated nitric acid $\left(\mathrm{HNO}_{3}\right)$ and concentrated per chloric acid $\left(\mathrm{HClO}_{4}\right)(\mathrm{v} / \mathrm{v})(\mathrm{Wei}$ et al. 2005). The concentrations of heavy metals in digest were determined using an atomic absorption spectrophotometer (VARIAN AA240).

\section{Statistical analysis}

Data were analyzed with statistical package Minitab 17 and SPSS 20. The differences among treatment were evaluated by one-way ANOVA $(p<0.05)$ according to the Tukey's multiple range test.

\section{Dry matter yield}

\section{RESULTS AND DISCUSSION}

Plant heights, fresh and dry weight of root and leaf were measured at different treatments (Table 1). Highest values of the height, fresh weight and dry weight of the root and leaf were observed in treatment receiving no $\mathrm{Cd}$ (Table 1). For the treatments maximum height $(17.6 \mathrm{~cm})$ was recorded in $\mathrm{T}_{2}$ treatment $(0.25 \mathrm{ppm} \mathrm{Cd} / 3 \mathrm{~kg}$ soil) $0.25 \mathrm{ppm}$ among the $\mathrm{Cd}$ treatments. However, no significant variation was observed among the $\mathrm{Cd}$ treated plants. The highest dry matter yield of the root $(4.26 \mathrm{~g} / \mathrm{plant})$ and leaf $(2.00 \mathrm{~g} / \mathrm{plant})$ were also achieved in $\mathrm{T}_{2}$ treatment. Total fresh weights of the root and leaf $(6.26 \mathrm{~g} / \mathrm{plant})$ were recorded highest also with the same treatment. The highest dry weights of the root ( $2.38 \mathrm{~g} / \mathrm{plant})$ and leaf $(0.79 \mathrm{~g} / \mathrm{plant})$ were also observed in the treatment having concentrations at $0.25 \mathrm{ppm}$. Total dry weights of the root and leaf $(3.17 \mathrm{mg} / \mathrm{kg})$ were also observed with the same treatment (Table 1).

Table 1. Effects of cadmium on dry matter yield of Chinese cabbage grown in soil.

\begin{tabular}{lccccccc}
\hline Treatments & Height $(\mathbf{c m})$ & \multicolumn{3}{c}{ Fresh weight(g/plant) } & \multicolumn{3}{c}{ Dry weight(g/plant) } \\
\cline { 3 - 8 } & & Root & Leaf & Total & Root & Leaf & Total \\
\hline (Control) & $17.9^{\mathrm{a}}$ & $4.58^{\mathrm{a}}$ & $2.02^{\mathrm{a}}$ & 6.6 & $2.82^{\mathrm{a}}$ & $0.87^{\mathrm{a}}$ & 3.69 \\
$0.0 \mathrm{ppm} \mathrm{Cd} / 3 \mathrm{~kg}$ soil & & & & & & & \\
$0.25 \mathrm{ppm} \mathrm{Cd} / 3 \mathrm{~kg}$ soil & $17.6^{\mathrm{a}}$ & $4.26^{\mathrm{b}}$ & $2.00^{\mathrm{a}}$ & 6.26 & $2.38^{\mathrm{b}}$ & $0.79^{\mathrm{b}}$ & 3.17 \\
$0.50 \mathrm{ppm} \mathrm{Cd} / 3 \mathrm{~kg}$ soil & $16.9^{\mathrm{a}}$ & $3.21^{\mathrm{c}}$ & $2.08^{\mathrm{b}}$ & 5.29 & $1.96^{\mathrm{c}}$ & $0.74^{\mathrm{b}}$ & 2.70 \\
$1.00 \mathrm{ppm} \mathrm{Cd} / 3 \mathrm{~kg}$ soil & $16.6^{\mathrm{a}}$ & $3.17^{\mathrm{c}}$ & $1.90^{\mathrm{c}}$ & 5.07 & $1.70^{\mathrm{d}}$ & $0.71^{\mathrm{b}}$ & 2.41 \\
$1.50 \mathrm{ppm} \mathrm{Cd} / 3 \mathrm{~kg}$ soil & $16.0^{\mathrm{a}}$ & $3.22^{\mathrm{c}}$ & $1.50^{\mathrm{d}}$ & 4.72 & $1.55^{\mathrm{e}}$ & $0.63^{\mathrm{c}}$ & 2.18 \\
$2.00 \mathrm{ppm} \mathrm{Cd} / 3 \mathrm{~kg}$ soil & $15.4^{\mathrm{a}}$ & $3.05^{\mathrm{d}}$ & $1.32^{\mathrm{e}}$ & 4.37 & $1.60^{\mathrm{e}}$ & $0.46^{\mathrm{d}}$ & 2.06 \\
$3.00 \mathrm{ppm} \mathrm{Cd} / 3 \mathrm{~kg}$ soil & $14.7^{\mathrm{a}}$ & $2.83^{\mathrm{e}}$ & $1.04^{\mathrm{f}}$ & 3.87 & $1.27^{\mathrm{f}}$ & $0.30^{\mathrm{e}}$ & 1.57 \\
$4.00 \mathrm{ppm} \mathrm{Cd} / 3 \mathrm{~kg}$ soil & $14.1^{\mathrm{a}}$ & $1.06^{\mathrm{f}}$ & $1.35^{\mathrm{g}}$ & 2.41 & $0.56^{\mathrm{g}}$ & $0.48^{\mathrm{f}}$ & 1.04 \\
$\mathrm{LSD}$ at $5 \%$ & 0.16 & 0.06 & 0.06 & - & 0.06 & 0.06 & - \\
\hline
\end{tabular}




\section{Tukey pair test}

Highest concentration of $\mathrm{Cd}$ was found in the treatment $3.00 \mathrm{ppm}$. However, the lowest concentration of $\mathrm{Cd}$ was found in the treatments 0.25 and $0.50 \mathrm{ppm}$. The concentration values of Cd varied significantly in the treatments $3.00,4.00,2.00,1.50,1.00$ and $0.50 \mathrm{ppm}$ although treatments 0.00 and 0.25 did not vary significantly (Table 2 ).

Table 2. Tukey pair wise comparison tests among treatments.

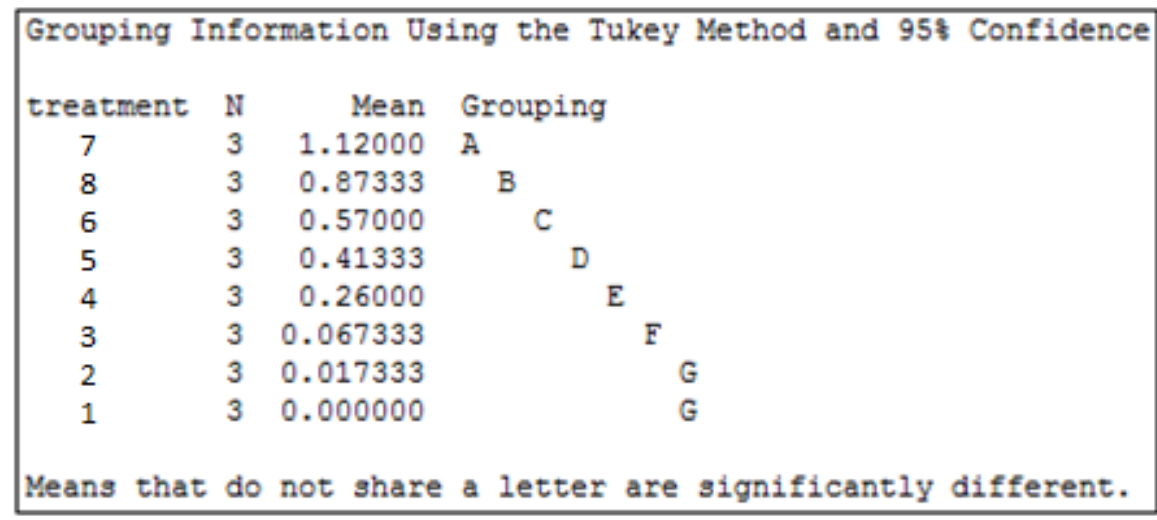

Accumulation of $C d$

Treatments caused variable accumulations of $\mathrm{Cd}$ in the leaf of Chinese cabbage (Fig. 1). Accumulated cadmium in the leaf was around 0.0, 0.023, 0.067, 0.26, 0.41, 0.57, 1.12, and 0.87 ppm, respectively. Accumulations showed marked variation among the treatments. The values of Cd increased sharply with increasing concentration except the $4 \mathrm{ppm}$ which decreases. The highest uptake was found in the $3 \mathrm{ppm}$ and that of the lowest was found in $0 \mathrm{ppm}$. There was no significant difference between 0 and 0.5 treatments (Fig. 1).

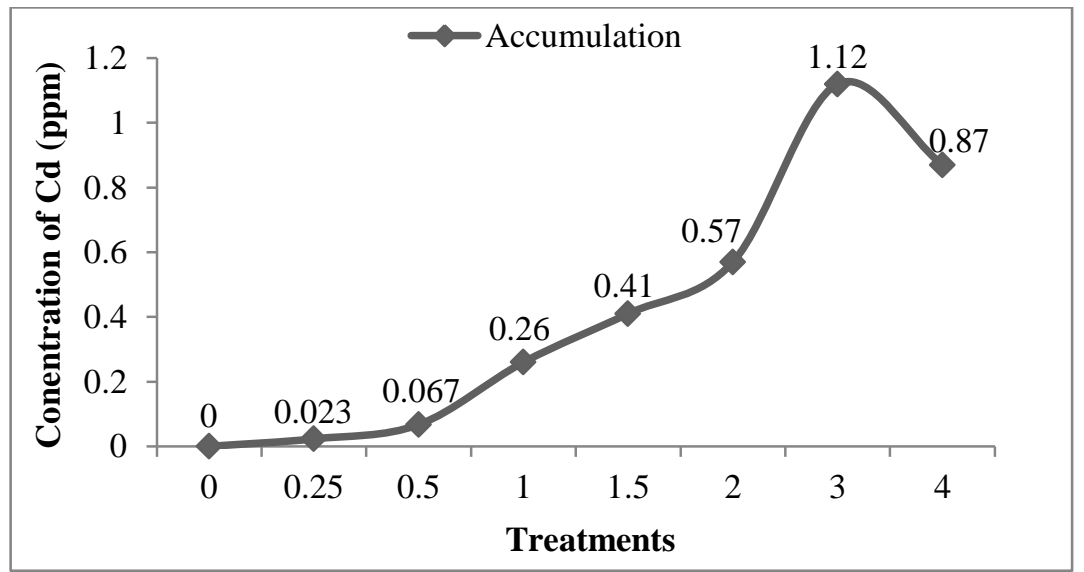

Fig. 1. Accumulation of $\mathrm{Cd}$ in the leaf of Chinese cabbage in different treatments.

However, other treatments caused significant variation in the doses of $\mathrm{Cd}$ applied. Highest concentration of $\mathrm{Cd}$ was found in the $3.0 \mathrm{ppm}$ treatment. However, the lowest concentration of $\mathrm{Cd}$ was found in the treatments $0-0.5 \mathrm{ppm}$. The decline in $\mathrm{Cd}$ concentration in the tissue of leaf at the highest concentration dose might be due to the toxic effect of the metal. 


\section{Bio-concentration factor $(B C F)$}

Bio-concentration factor (BCF) is a ratio of total cadmium accumulation in plant to soil was calculated where plant were grown

$$
B C F=\frac{C_{\text {vegetable }}}{C_{\text {soil }}}
$$

In this study, several bio-concentration factors were found that were associated with the treatments. Bio-concentration factors of the treatments $0-4 \mathrm{ppm}$ of cadmium were adjusted and the values were around $0.0,0.092,0.134,0.26,0.27,0.29,0.37$ and $0.22 \mathrm{ppm}$, respectively. The highest amount of BCF was found in the treatment receiving $3.0 \mathrm{ppm}$ of Cadmium whereas the lowest measure of BCF was recorded in the $0.0 \mathrm{ppm}$ treatment of cadmium. The $\mathrm{BCF}$ was augmented with the increment of cadmium up to $3 \mathrm{ug} /$ pot and declined thereafter (Fig. 2).

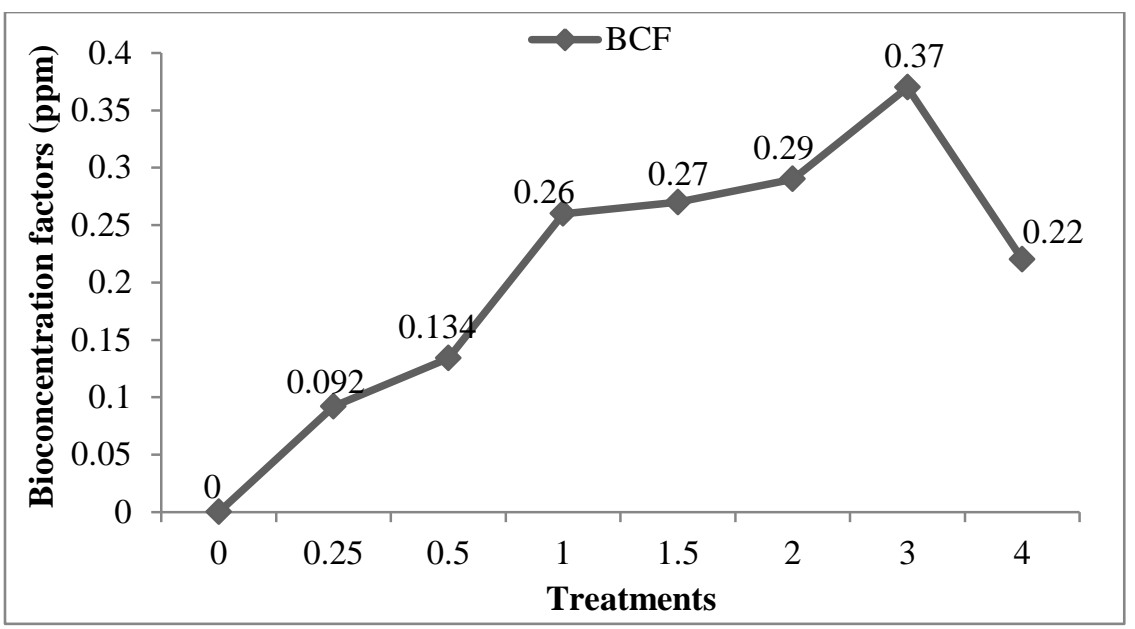

Fig. 2. Bio-concentration factor $(\mathrm{BCF})$ of $\mathrm{Cd}$ for different treatments.

\section{Target Hazard Quotient (THQ)}

The THQ value determines the potential risk that is associated with the cadmium accumulation. If THQ is less than 1 , no risk associated with the consumption but higher than 1 is potentially toxic.

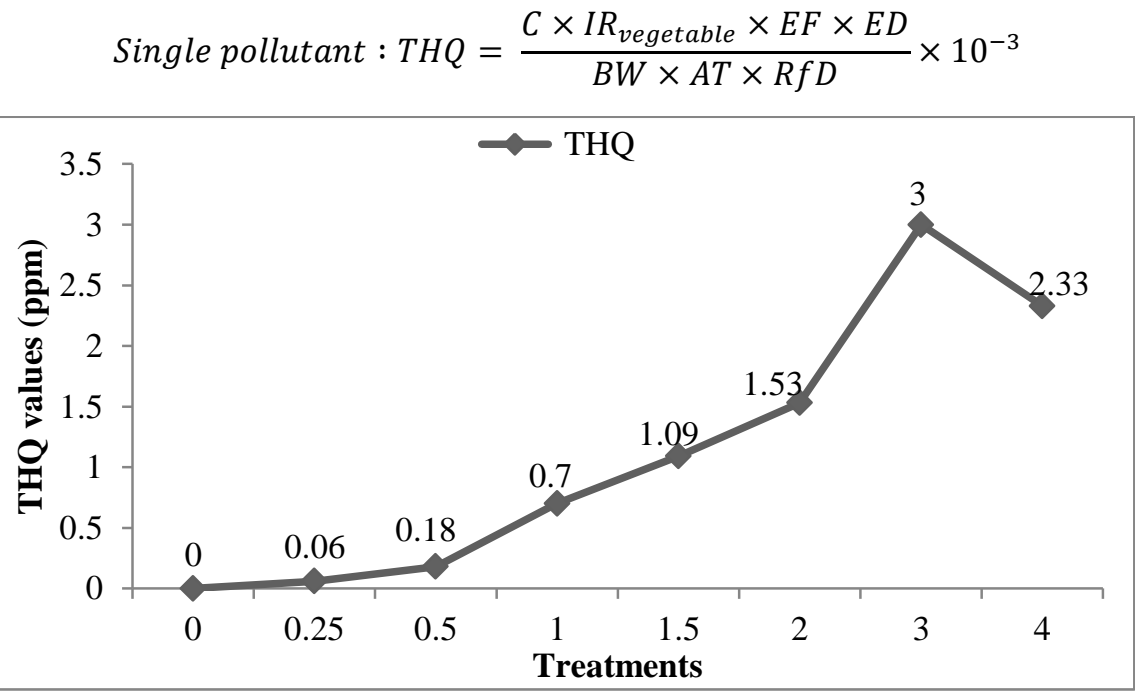

Fig. 3. Target Hazard Quotient (THQ) of different treatments applied Chinese cabbage. 
In Bangladesh, exposure frequency per year (days/year), $\mathbf{E F}=90 / 365=0.24$; in urban area, the vegetable ingestion rate per day (g/day), $\mathbf{I R}=155 \mathrm{~g}$; exposure duration (year); $\mathbf{E D}=70.7$ years, average weight of local residency, $\mathbf{B W}=57.7 \mathrm{~kg}$; average exposure time for non-carcinogens, $\mathbf{A T}=\mathrm{EF} \times 70.7$ years $=16.96$; oral reference dose, RFD $=0.001 \mathrm{mg} / \mathrm{kg}$-day (Finucane et al. 2011, BSS 2010, Foulkes 1986).

With increasing concentration of $\mathrm{Cd}$ in soil, bio-concentration factors of $\mathrm{Cd}$ in Chinese cabbage (Brassica campestris var. pekinensis) also increased except at $4 \mathrm{ppm}$. As far as human health is concerned, Chinese cabbage grown in Cd contaminated soils contenting $1.0 \mathrm{ppm}$ might be safe. However, Chinese cabbage grown on the soils with $\mathrm{Cd}$ content 2.0, 3.0 and 4.0 ppms were risky and may cause serious health hazard to human body. From the study, it is clear that Chinese cabbage can be cultivated in $\mathrm{Cd}$ contaminated soil containing maximum $1 \mathrm{ppm} \mathrm{Cd}$ which will not cause any risk beyond which it is extremely risk for health.

Not only Chinese cabbage, but also all other consumable vegetables are similarly contaminated through the process of bioaccumulation of heavy metals by passing the successive trophic levels in an ecosystem (Woodwell 1967). The present paper deals with only one (Cd) heavy metal. Movement of all heavy metals follows more or less the same pattern but accumulation or/and concentrations in parts per million (ppm) are varied depending on the number of trophic levels are involved. However, these heavy metals as per their movement pathways and rate of concentrations cause manifold impacts on depleting bioresources (including humans) through bioaccumulation almost in all ecosystems. This biological process has been occurring in nature very often by the anthropogenic activities.

\section{REFERENCES}

Aktaruzzaman, M., A. N. M. Fakhruddin, M. A. Z. Chowdhury, Z. Fardous and M. K. Alam. 2013. Accumulation of heavy metals in soil and their transfer to leafy vegetables in the region of Dhaka Aricha Highway, Savar, Bangladesh. Pakistan J. Biol. Sci. 16(7): 332-338.

Alam, M. G. M., E. T. Snow and A. Tanaka. 2003. Arsenic and heavy metal concentration of vegetables grown in Samta village, Bangladesh. Sci. Total Environ. 111: 811-815.

Bangladesh Bureau of Statistics (BBS). 2015. Statistics Division, Ministry of Planning, Government of the People's Republic of Bangladesh. 41 pp.

Bangladesh Bureau of Statistics (BBS). 2010. Statistics Division, Ministry of Planning, Government of the People's Republic of Bangladesh. 48 pp.

Bashar, M. A. 2004. Instant Basics of Environment: wide approach to nature lover. Positron publications, 38/2/ka Banglabazar, Dhaka-1100. 578 pp.

Bhuiyan, M. A. H., N. I. Suruvi, S. B. Dampare, M. A. Islam, S. B. Quraishi, S. Ganyaglo and S. Suzuki. 2011. Investigation of the possible sources of heavy metal contamination in lagoon and canal water in the tannery industrial area in Dhaka, Bangladesh. Environ. Monit. Assess. 175: 633649.

Brioschi, L., M. Steinmann, E. Lucot, M. C. Pierret, P. Stille, J. Prunier and P. M. Badot. 2013. Transfer of rare earth elements (REE) from natural soil to plant systems: Implications for the environmental availability of anthropogenic REE. Plant Soil. 366: 143-163.

Conway, G. R. and Pretty J. N. 1991. Unwelcome harvest agriculture and pollution. Earth scan Publications Ltd, London, UK. 672 pp.

De, A. K. 1989. Environmental Chemistry. Wiley Eastern Limited, New Delhi. 390 pp. 
Delgado, J., R. Perez-Lopez, L. Galvan, J. M. Nieto and T. Boski. 2012. Enrichment of rare earth elements as environmental tracers of contamination by acid mine drainage in salt marshes: A new perspective. Marine Pollution Bulletin. 64(9): 1799-1808.

Finucane, M. M., G. A. Stevens, M. J. Cowan, G. Danaei and J. K. Lin. 2011. National, regional, and global trends in body-mass index since 1980: Systematic analysis of health examination surveys and epidemiological studies with 960 country-years and 9.1 million participants. Lancet. 377: 557567.

Foulkes, E. C. 1986. Absorption of cadmium. In: E. C. Foulkes (ed.). Handbook of Experimental Pharmacology. Vol. 80. Springer Verlag, Berlin., pp. 75-100.

Jackson, M. L. 1958. Soil Chemical Analysis. Prentice-Hall, Inc., Englewood Cliffs, NJ. 498 pp.

Jackson, M. L. 1967. Soil Chemical Analysis. Prentice Hall of India Pvt. Ltd. New Delhi. 498 pp.

Khan, S., S. Rehman, A. Z. Khan, M. A. Khan and M. T. Shah. 2010. Soil and vegetables enrichment with heavy metals from geological sources in Gilgit, Northern Pakistan. Ecotoxicol. Environ. Safety. 73(7): 1820-1827.

Klute, A. (Ed.) 1986. Methods of Soil Analysis. Agron. Series 9. American Society of Agronomy, Inc. Publ., Madison, Wisconsin, USA. 28 pp.

Liu, L., L. L. Hu, J. J. Tang, Y. F. Li, Q. Zhang and X. Chen. 2012. Food safety assessment of planting patterns of four vegetable-type crops grown in soil contaminated by electronic waste activities. $J$. Environ. Manage. 93(1): 22-30.

Marr, I. L. and M. S. Cresser. 1983. Environmental Chemical Analysis: The Lithosphere. Blackie and Son. UK, pp. 155-182.

Mengal, K. and E. A. Kirkby. 1987. Principles of Plant Nutrition. International Potash Institute, Switzerland.

Muller, G. 1969. Index of geo-accumulation in sediments of the Rhine River. Geojournal. 2: 108-118.

Ngole, V. M. 2011. Using soil heavy metal enrichment and mobility factors to determine potential uptake by vegetables. Plant, Soil and Environ. 57(2): 75-80.

Pandey, J. and U. Pandey. 2009. Accumulation of heavy metals in dietary vegetables and cultivated soil horizon in organic farming system in relation to atmospheric deposition in a seasonally dry tropical region of India. Environ. Monitor. Assess. 148(1-4): 61-74.

Piper, C. S. 1944. Soil and Plant Analysis. The University of Adelaide, Australia., pp. 47-79.

Rashid, M. M. 1999. Sabji Biggan. Rashid Publishing House, 94, Old DOHS, Dhaka- 1206. 248 pp.

USEPA. 2005. Human health risk assessment protocol for hazardous waste combustion facilities. National Service Center for Environmental Publications (NSCEP), Office of Solid Waste, USA. $810 \mathrm{pp}$.

USEPA. 2002. Preliminary Remediation Goals. U.S. Environmental Protection Agency, Region 9, Washington DC. 29 pp.

USEPA. 1989. Risk Assessment: Guidance for Superfund. In: Human Health Evaluation Manual (PartA). Interim Final, Vol. 1. Office of Emergency and Remedial Response, U. S. Environmental Protection Agency, Washington DC. 291 pp. 
Woodwell, G. M. 1967. Toxic substances and ecological cycles. Sci. Amer. 216(3): 24-31.

Wei, S., Q. X. Zhou and X. Wang. 2005. Identification of weed plants excluding the absorption of heavy metals. Environ. Int. 31: 829-834.

Zhou, Q. X., L. P. Ren, T. H. Sun and X. Wang. 2002. Soil contaminated by Cd and its interface process in a Pb-Zn mine. Chin. Bull. Soil Sci. 33: 300-302.

Zhou, Q. X. 2003. Interaction between heavy metals and nitrogen fertilizers applied in soil-vegetable systems. Bull. Environ. Contam. Toxicol. 71: 388-344.

Zoller, W. H., E. S. Gladney and R. A. Duce. 1974. Atmospheric concentrations and sources of trace metals at the South Pole. Science. 183: 199-201. 